\title{
The Place of Human Beings in the Natural Environment Aristotle's Philosophy of Biology and the Dominant Anthropocentric Reading of Genesis
}

Giulia Mingucci

In a seminal essay from 1967, historian Lynn White, Jr., argues that the profound cause of today's environmental crisis is the anthropocentric perspective, embedded in the Christian "roots" of Western tradition, which assigns an intrinsic value to human beings solely. Though White's thesis relies on a specific tradition - the so-called "dominant anthropocentric reading" of Genesis - the idea that anthropocentrism provides the ideological basis for the exploitation of nature has proven tenacious, and even today is the ground assumption of the historical and philosophical debate on environmental issues. This paper investigates the possible impact on this debate of a different kind of anthropocentrism: Aristotle's philosophy of biology. The topic is controversial, since it involves opposing traditions of interpretations; for the purpose of the present paper, the dominant anthropocentric reading of Gen. 1.28 will be analyzed, and the relevant passages from Aristotle's De Partibus Animalium, showing his commitment to a more sophisticated anthropocentric perspective, will be reviewed.

\section{Introduction}

In a much cited essay from 1967, "The Historical Roots of Our Ecological Crisis", historian Lynn White, Jr., argued that Western Christianity has a long historical legacy of anthropocentrism. The meaning of anthropocentrism is not uncontroversial. ${ }^{2}$ In its original connotation in environmental ethics, and thus in an axiological sense ${ }^{3}$, anthropocentrism is the belief that "human beings, and human beings only, are of intrinsic value (that is, valuable in and of themselves) and that non-human nature is valuable for

\footnotetext{
${ }^{1}$ Lynn White, "The Historical Roots of our Ecological Crisis", Science 155 (1967): 1203-1207.

${ }^{2}$ See e.g. Eugene C. Hargrove, "Weak Anthropocentric Intrinsic Value", The Monist 75 (1992) 2: 183-207; William Grey, "Environmental Value and Anthropocentrism", Ethics and the Environment 3 (1998) 1: 97-103.

${ }^{3}$ Cf. Alain Ducharme, “Aristotle and the Dominion of Nature”, Environmental Ethics 36 (2014) 2: 203-214 at 207.
} 
human purposes (that is, valuable instrumentally - extrinsically - for its ability to serve human ends)". ${ }^{4}$ Because the intrinsically valuable is that which is good as an end in itself, it is commonly agreed that something's possession of intrinsic value generates a direct moral duty on the part of moral agents to protect it or at least refrain from damaging it. ${ }^{5}$ Then it is also held that axiological anthropocentrism, by assigning intrinsic value to human beings alone, not only places ơ $v \theta \rho \omega \pi \mathrm{o} \zeta$ at the center of ethical concerns, but also and especially displaces the other-than- $\alpha v \theta \rho \omega \pi$ o $s$ to the periphery ${ }^{6}$, thus providing the conditions for human supremacy and exploitation of the natural environment and its nonhuman content.

It is not the aim of this paper to enter in the complex debate on the actual role of Christian theology on the rise of modern science and technology along with their exploitative consequences on the natural environment. This paper's goal is far more narrow: namely it is to draw attention to Aristotle's philosophy of biology as an alternative perspective to axiological anthropocentrism. To this aim, I will first analyze the axiological anthropocentric perspective which is tied to the so-called "dominant reading" of Genesis, by showing that it is constituted by three basic claims: anthropocentric teleology, human ontological superiority, and human dominion. Then, I will argue that Aristotle's biological treatises undermines this threefold connection by giving intrinsic value also the nonhuman content of living nature.

\section{The Dominant Anthropocentric Reading of Genesis}

According to Lynn White, human ecology is deeply influenced by religion. In particular, "the historical root of our ecological crisis" is represented by the JudeoChristian view that humans are superior over all other forms of life on earth, and that the whole creation has been arranged for their benefit and rule:

\footnotetext{
${ }^{4}$ David Keller, ed., Environmental Ethics: The Big Questions (Chichester, West Sussex: Wiley, 2010), 4.

${ }^{5}$ Cf. Andrew Brennan and Yeuk-Sze Lo, "Environmental Ethics", in Edward N. Zalta, ed., The Stanford Encyclopedia of Philosophy (Summer 2020 Edition). URL $=<$ https://plato.stanford.edu /archives/sum2020/entries/ethics-environmental/>

${ }^{6}$ For the displacement of the nonhuman brought about by axiological anthropocentrism, see esp. Eileen Crist and Helen Kopnina, "Unsettling Anthropocentrism" and Matthew Calarco, "Being Toward Meat: Anthropocentrism, Indistinction, and Veganism" in Dialectical Anthropology 38 (2014) 4: 387-396 and 415-429 (respectively).
} 
God planned all of this explicitly for man's benefit and rule: no item in the physical creation had any purpose save to serve man's purposes. Especially in its Western form, Christianity is the most anthropocentric religion the world has seen. [...]. Christianity, in absolute contrast to ancient paganism and Asia's religions (except, perhaps, Zoroastrianism), not only established a dualism of man and nature but also insisted that it is God's will that man exploit nature for his proper ends. (Lynn White, "The Historical Roots of our Ecological Crisis", cit., at 1205.)

In White's interpretation, the Christian doctrine of the creation sets the human being apart from nature, advocates human dominion over nature, and implies that the natural world was created solely for human benefit. The biblical text that best exemplifies this view is Genesis 1.28:

[T2] And God blessed them, and God said to them "Be fruitful and multiply, and fill the earth and subdue it; and have dominion over the fish of the sea and over the birds of the air and over every living thing that moves upon the earth". (Genesis I.28) ${ }^{7}$

This verse contains a blessing (“God blessed them”), one imperative about human sexuality ("Be fruitful and multiply"), and another that stresses human dominion over the earth and God's other creatures ("subdue [...] have dominion"). ${ }^{8}$ It is especially the latter that has been blamed by White and many other ideologues of the ecology movement for giving human beings the license to exploit the environment for their own benefit without regard for the consequences. White in particular argues that the human dominion on earth referred to in Genesis is deeply implicated in the rise of Western modern science and the technological mastery of nature that it enabled. ${ }^{9}$

White's thesis relies on a very influential interpretation of Genesis, according to which mankind are entitled to subjugate the earth and its creatures on the basis of a divine imperative. This interpretation, which I shall call the "dominant anthropocentric reading

\footnotetext{
${ }^{7}$ The Holy Bible, Revised Standard Version (Toronto, New York, Edinburgh: Thomas Nelson \& Sons, 1952).

${ }^{8}$ Though the Hebrew terms for 'subdue' (kabash) and 'have dominion' (rada) are not as strong as their translation in modern languages suggest, they however refer to human sovereignty: kabash refers to tillage, and rada to governance. Cf. Peter Harrison, "Subduing the Earth: Genesis 1, Early Modern Science, and the Exploitation of Nature," The Journal of Religion 79 (1999) 1: $86-109$ at 88.

${ }^{9}$ Lynn White, "The Historical Roots", cit., 1205-1206. White finds evidence of attempts at the technological mastery of nature already in the Christian Middle Ages. Whereas the rhetoric of scientific progress in the seventeenth century incorporated explicit references to the text of Genesis, the medieval "conquest of nature" found its justification for the most part in pragmatic rather than ideological concerns. On the topic, see Peter Harrison, "Subduing the Earth", cit., esp. at $90-102$.
} 


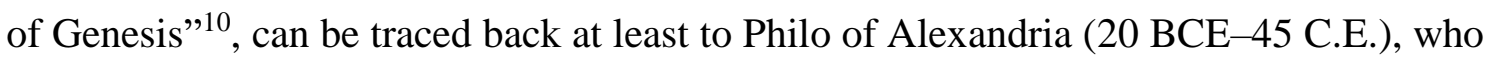
especially insisted on the theme of human dominion on earth. ${ }^{11}$ His treatment of Gen. 1.28 in the De Opificio Mundi (77-88) appears to be deeply influenced by his Stoic background, and especially by the Stoics' affirmation of an "anthropocentric teleology",


beings. In Philo, anthropocentric teleology goes hand in hand with humanity's ontological superiority over the rest of creation, above all in the possession of reason. Nonetheless, human beings are not the only rational beings: Philo holds that heavenly beings are rational beings standing higher than human beings on the ontological scale; so, human beings are subject to them. By taking, in accordance with Stoic cosmology, reason as the governing principle, Philo constructs his image of the cosmos as a system of rulership, where the only true ruler is God, followed by heavenly things and lastly by human beings. Human dominion is thus limited only to the "sublunary things"- as actually a literal reading of Genesis would suggest ("fill the earth and subdue it").

Philo's interpretation of T2 might therefore be analyzed in the following three claims:

[A] Anthropocentric Teleology: Human natural environment (i.e. the earth) and its nonhuman content exist only for the sake of human beings.

[S] Ontological Superiority of Human Beings: Reason places human beings higher than other (earthy) beings on the ontological scale.

[D] Human Dominion: Human beings have the right to rule their natural environment and its nonhuman content.

This threefold connection, [A] anthropocentric teleology, [S] human ontological superiority and [D] dominion, paved the way to a "utilitarian" approach to the natural environment $^{12}$ : on the one hand, God has given human beings reason, and with this the right to rule the world; on the other, God has prepared a world serviceable to human

\footnotetext{
${ }^{10}$ I borrow this expression from Ronald A. Simkins, "The Bible and Anthropocentrism: Putting Humans in Their Place", Dialectical Anthropology 38 (2014) 4: 397-413.

${ }^{11}$ For what follows, cf. David Jobling, “"And Have Dominion...': The Interpretation of Genesis 1,28 in Philo Judaeus," Journal for the Study of Judaism in the Persian, Hellenistic, and Roman Period 8 (1977) 1: 50-82 (esp. 52-60).

12 This connection is found very widely outside of Philo, for example in Tertullian: for further references, see David Jobling, “"And Have Dominion...", cit., 52 note 8. For full documentation, see David Jobling, 'And Have Dominion...', Dissertation (New York: Union Theological Seminary, 1972).
} 
beings. ${ }^{13}$ By maintaining the superiority of humans over all life forms on earth, and by depicting all life forms as existing for the use of humans, the dominant anthropocentric reading of Genesis is the fullest expression of axiological anthropocentrism, according to which only humans are of intrinsic value, while nonhumans are valuable just instrumentally. ${ }^{14}$

Against the dominant anthropocentric reading of $\mathrm{T} 2$, one may argue that the Genesis verse is primarily a pronouncement about human place in the Creation on the borderline between divinity (given by rationality) and animality (given by mortality and bodily affections) rather than a conferral of a license to exploit the earth. ${ }^{15}$ This line of interpretation, however, would not confute Lynn White's main argument. White's thesis is not concerned with the meaning of the text as such, but rather with the history of the interpretation of the text. His crucial question is therefore how Genesis may plausibly have been read to inspire and justify massive technological transformations of the environment. ${ }^{16}$ His answer is: anthropocentrically. Most likely, this was a cultural imposition on it; but by making human ontological superiority ([S]) go hand in hand with anthropocentric teleology ([A]) and dominion ([D]), the dominant anthropocentric reading paved the way to centuries of interpretation which invoked Gen. I.28 to enforce value systems based on the idea of human exploitation of nature.

${ }^{13}$ Cf. David Jobling, “"And Have Dominion...”, cit., 56. Compare T1: "God planned all of this [i.e. the whole creation] explicitly for man's benefit and rule: no item in the physical creation had any purpose save to serve man's purposes."

${ }^{14}$ Cf. Eugene C. Hargrove, "Weak Anthropocentric Intrinsic Value," cit., at 183.

${ }^{15}$ See esp. Jeremy Cohen, "Be Fertile and Increase, Fill the Earth and Master It": The Ancient and Medieval Career of a Biblical Text (Ithaca, N.Y., and London: Cornell University Press, 1989). The conclusion of his extensive study on the history of the interpretation of Gen. 1.28 is that "the primary meaning of Gen. 1.28 during the period we have studied [i.e. ancient and medieval times] [is] an assurance of divine commitment and election, and a corresponding challenge to overcome the ostensive contradiction between the terrestrial and the heavenly inherent in every human being."

${ }^{16}$ Cf. J. Baird Callicott, "Genesis Revisited: Murian Musings on the Lynn White, Jr. Debate", Environmental History Review 14 (1989) 1/2: 65-90 at 86. Compare Roderick Nash, The Rights of Nature (Madison: University of Wisconsin Press, 1988): 89; Peter Harrison, "Subduing the Earth", cit., 89-90. 
Aristotle's Defense of Biology: De Partibus Animalium I.5

Along with the dominant anthropocentric interpretation of the biblical tradition, at the roots of Western science there is also another fundamental source: the Aristotelian corpus of biological writings. Aristotle's inquiries on comparative anatomy and physiology are not only the largest part of his corpus of works, but also, and especially, the most creative part of his intellectual maturity and the foundation of a new scientific discipline, biology. Nonetheless, despite their influence in the history of medieval, early modern and modern scientific thought ${ }^{17}$, in late antiquity they were not considered of great interest. ${ }^{18}$ There seems to be a basic reason for this ${ }^{19}$ : for philosophers of late antiquities, who were essentially Platonic, the study of the sensible world had an anagogic function, i.e. it served to direct the soul toward the study of the intelligible world. Thus they had a "selective approach" to Aristotle's writings on natural philosophy, an approach which was substantially motivated by their concerns of anthropology and theology. Compared to the observation of plants and animals, the observation of celestial bodies was certainly considered more appropriate to prepare the soul for the study of higher things. Aristotle himself witnessed a similar prejudice toward biology, and it is precisely to defend the dignity of this new discipline from that prejudice that he composed a passionate speech: De Partibus Animalium I.5. ${ }^{20}$

The text is actually a defense of the study of the most humble beings: Aristotle invites his audience not to omit anything around them, because to $\theta \varepsilon \omega \rho i ́ \alpha$ everything, even the most repulsive thing, presents its own beauty. Aristotle declares that he has

\footnotetext{
${ }^{17}$ Renaissance medicine is proof of their influence (see esp. Stefano Perfetti, Aristotle's Zoology and Its Renaissance Commentators [1521-1601] [Leuven: Leuven University Press, 2000]), but it is sufficient to think of the success of Aristotle's scientific terminology, which remained in force until Linnaeus's system of classification (1707-1778): on this latter aspect, see e.g. Wolfgang Kullmann, Aristoteles und die Moderne Wissenschaft (Stuttgart 1998).

${ }^{18}$ James G. Lennox, “The Disappearance of Aristotle's Biology: A Hellenistic Mystery”, Apeiron 27 (1994): 7-24.

${ }^{19}$ Cf. esp. Andrea Falcon, Aristotelismo (Torino: Einaudi, 2017), at 105-106. See also Cristina Cerami and Andrea Falcon, "Continuity and Discontinuity in the Greek and Arabic Reception of Aristotle's Study of Animals", Antiquorum Philosophia, 8 (2014): 35-56.

${ }^{20}$ On Aristotle's polemical aims in De Partibus Animalium I.5, see Giulia Mingucci, "Una difesa dello studio della materia vivente: Aristotele, De Partibus Animalium I 5", Antiquorum Philosophia 14 (2020), pp. 159-175.
} 
already dealt with the celestial region of the natural world and the celestial bodies ${ }^{21}$, and that he now wants to continue his natural research by dealing with sublunary living nature (645a4-5). According to him, this research has equal dignity than "sidereal theology"22, and it might reserve extraordinary pleasures to those who are by nature philosophers, even when it is directed to apparently repulsive realities:

[T3] Since we have completed stating the way things appear to us about the divine things, it remains to speak about living nature, omitting nothing in our power, whether of lesser or greater value. For even in the study of things disagreeable to perception, the nature that crafted them likewise provides extraordinary pleasures to those who are able to know their causes and are by nature philosophers. (Aristotle, De Partibus Animalium I.5, 645a4-10)23

The pleasures of biological inquiries are "extraordinary" $(645 \mathrm{a} 9)$ because their objects have something $\theta \alpha v \mu \alpha \sigma \tau o ́ v$ (645a17; cf. 645a23). To the eyes of Aristotle, the ever-changing processes of generation and corruption characterizing living reality have

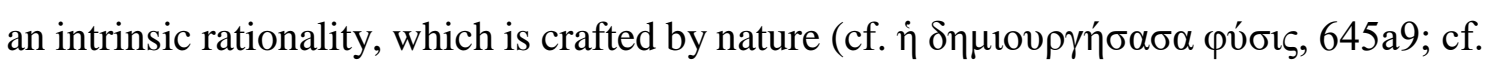
GA I.23, 731a24). ${ }^{24}$ It is precisely in this intrinsic rationality that the dignity and beauty - in a word, the intrinsic value - of natural objects reside. The way nature works, compared to that of a painter or a sculptor (cf. 645a12-13), is ordered with a view to an end:

${ }^{21}$ The reference is almost certainly to the first two books of De Caelo. For Aristotle's natural philosophy "work plan", see Meteor. I 1, 338a20-339a10 with Andrea Falcon, Aristotle and the Science of Nature (Cambridge: Cambridge University Press, 2005) at 2-7; James G. Lennox, "The Place of Zoology in Aristotle's Natural Philosophy", in Robert W. Sharples, ed., Philosophy and the Sciences in Antiquity (Aldershot: Ashgate, 2005): 58-70 at 59-65.

${ }^{22}$ On astronomy as a "théologie sidérale", see J.M. Le Blond (ed.), Aristote philosophe de la vie: Le livre premier du traité sur les Parties des Animaux (Paris: Aubier Éditions Montaigne, 1945): 182 ad PA 644a25 (sic).

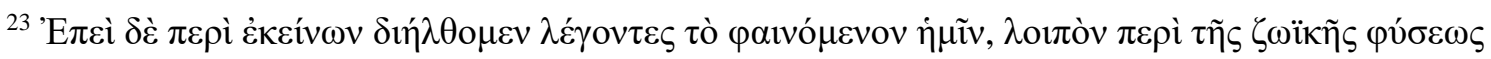

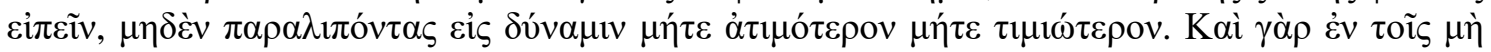




J. Louis, Aristote: Les parties des animaux (Paris: Les Belles Lettres, 1956); tr. by James G. Lennox, Aristotle: On the Parts of Animals I-IV (Oxford: Oxford University Press, 2001), slightly modified.

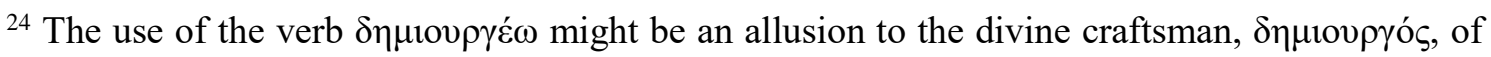
Plato's Timaeus: J.-M. Le Blond, Aristote philosophe de la vie, cit., at 46 and at 184 ad PA $645 \mathrm{a} 9$. For the influence of Plato's artisan model on Aristotelian teleology, and its transformation from a "divine" to a "natural" model, see Thomas K. Johansen, "From Craft to Nature: The Emergence of Natural Teleology", in L. Taub, ed., The Cambridge Companion to Ancient Greek and Roman Science (Cambridge: Cambridge University Press, 2020): 102-120. 
[T4] For what is not haphazard but rather for the sake of something is in fact present most of all in the works of nature; the end for the sake of which each has been constituted or comes to be takes the place of the good. (Aristotle, De Partibus Animalium I.5, 645a23-26) ${ }^{25}$

The end is relative to each natural reality and governs its generation, development and corruption. This is the reason why for Aristotle all natural things, from the highest to the most humble, possess, in equal measure, something $\theta \alpha v \mu \alpha \sigma \tau o ́ v:$ everything is constituted in view of its own intrinsic end, and this is "marvelous" to Aristotle.



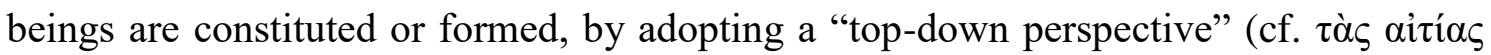
$\kappa \alpha \theta 0 \rho \tilde{\alpha} v, 645 \mathrm{a} 15)$, that is, the perspective of the form and the end, is the distinguishing feature of the true philosopher of nature. This ability results in a perspective on sensible realities different from the one which the visual organ is responsible for. Scientific

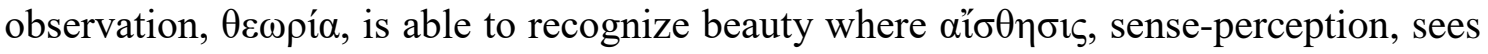
only "disagreeable" realities (645a7-10). Aristotle therefore invites his audience to "omit





Among the aspects of living nature which are of "lesser value" Aristotle includes lower animals ${ }^{26}$ : the study of them could in fact be considered to "lack value" (645a27; cf. 645a15) and even to provoke "disgust" (645a22). The expression 'lower animals' denotes the members of the group that Aristotle typically calls "bloodless", which roughly corresponds to that of invertebrates: insects, testacea, crustacea, and cephalopods, which are all "imperfect" ( $\dot{\alpha} \tau \varepsilon \lambda \varepsilon \tilde{\imath} \varsigma)$ animals (cf. esp. HA I.9, 491b26-27; GA III.9, 758b15-21). This group of animals is considered by Aristotle of lesser value with respect to the "blooded" (vertebrates) and especially to the human being:

[T5] Animals of greater value have more heat; for they must at the same time have a soul of greater value; for they have a nature of greater value than that of fishes. So the animals which have a lung with the most blood and heat are greater in size, and that whose blood is purest and in the greatest quantity of all living creatures is the most erect, that is to say man; "up" in his case

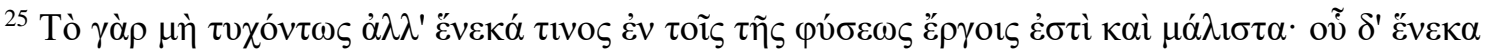


modified.

${ }^{26}$ Biological matter is also included among the aspects "of lesser value" of living nature. In this context, however, I will deal only with animal kingdom. For matter, see Giulia Mingucci, "Una difesa dello studio della materia vivente", op. cit.
} 
corresponds to "up" in the whole universe just because he has such a lung. (Aristotle, De Respiratione 13, 477a16-23 $)^{27}$

Aristotle's use of the comparative degree of the adjectives $\tau i ́ \mu 10 \varsigma$ and ö $\tau \mu$ o (see esp. T4: 645a7; T5: 477a16, 17, 18) suggests that the so-called "inferior" animals are not absolutely valueless: each animals has its own "value" according to a continuous and gradual scale, from the most perfect or complete to the least perfect and complete:

[T6] In fact nature passes continuously from soulless things into animals by way of those things that are alive yet not animals, so that by their proximity the one seems to differ very little from the other. (Aristotle, De Partibus Animalium IV.5, 681a12-15) ${ }^{28}$

A passage from De Partibus Animalium IV.10 (686a24-687a2) is illustrative of Aristotle's idea of the "continuity" of nature. There, Aristotle arranges the animal genera in successive levels according to the quantity of earthen material and connate heat present in their constitution. Earthen material and connate heat are connected to the posture and the number of feet of an animal species: heat directs the growth of the body according to the direction proper to the natural place of fire, the top; earth instead directs the growth of the body downwards, which is the earth's natural place. So connate heat is responsible for upright posture; the decrease in connate heat and the increase of the earthen material corresponds to a progressive flattening of the body toward earth and the multiplication of feet. It is therefore outlined a scala naturae according to degrees of bodily heat: the maximum level is occupied by the human being, who is the warmest animal and thus the only one to have an upright posture; followed by the four-footed, the many-footed, and finally the footless animals. Aristotle adds that, "proceeding in this way a little [...] a plant comes to be, having the above below, and the below above" (686b32-35).

Gradualness also appears in the classification of animal genera and species. Aristotle in fact bases his animal classification on the criteria of "the more and the less" and of analogy (cf. esp. HA VIII.1, 588b4-13; PA IV.5, 681a12-15; 10, 686a27-b3;



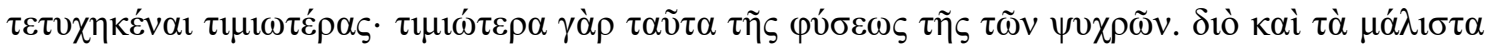



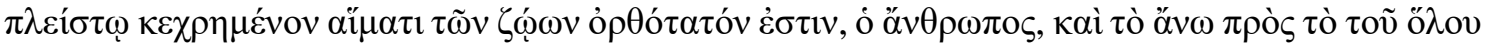

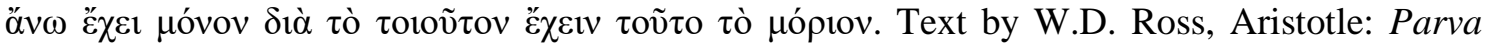
naturalia (Oxford: Clarendon Press, 1955). Tr. by W.S. Hett, Aristotle: On the Soul, Parva Naturalia, On Breath (Cambridge, Mass., London: Loeb, 1957), slightly modified.

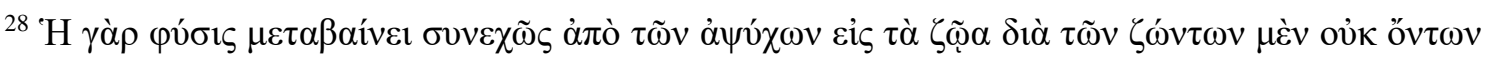




686b29-687a2; GA II.1, 732b28-733b16). Animals belonging to a single genus have bodily parts similar in configuration but different with regard of sensible qualities (greatness and smallness, softness and hardness). These differences are gradually disposed in a scale according to the principle of "the more and the less:" for example, two birds (i.e. two animals of the same genus but of different species) differ from each other because the one has larger, the other smaller, wings (cf. PA I.4, 644a19-21). On the other hand, animals of different kinds, such as birds and fish, have different bodily parts comparable by analogy. In other words, they are different parts that perform the same function: for example, it is possible to compare bird feathers to fish scales on the basis of their common function of protection (cf. PA I.4, 644a21-22).

The principles of the more and the less and analogy confirm that nature is conceived by Aristotle as a continuous order, where animals belonging to different genres are compared by analogy and those belonging to the same genus vary in gradual quantitative aspects. This idea is confirmed in the different contexts in which Aristotle compares the human being to other animals: for Aristotle there is a gradualness not only in the possession of physical characteristics such as connate heat and earthy material, but also in the possession of psychical qualities (cf. HA VIII.1, 588a18-b3) and "social" features (cf. Pol. I.2, 1253a7-8).

\section{The Human Being among Bearers of Intrinsic Value}

Aristotle explicitly attributes greater value to human beings than to other species (cf. e.g. PA II.10, 656a7-8; IV.10, 686a27-28, 686b23-24, 687a9-10, 18-19; IA 4, 706a19$20 ; 5,706 \mathrm{~b} 10)$. This does not mean, however, that the human being is placed at the top of a rigid zoological taxonomy. For Aristotle, living nature is arranged according to a continuous and gradual order, a scale of gradation of perfection where differences between human beings and other animals are conceived simply as morphological and functional variations. In this zoological order, the human being occupies a "special place" for his possession of the intellective capacity, which teleologically determines his other psychological powers and his bodily features. ${ }^{29}$

\footnotetext{
${ }^{29}$ On the topic, see e.g. Andrea Libero Carbone, “Anomalies de l'intelligence, intelligence de l'anomalie: Note sur la représentation de l'organisation du corps vivant chez Aristote entre les Parva Naturalia et les Problèmes," in C. Grellard and P.-M. Morel, ed., Les Parva Naturalia
} 
Given the special role mankind has in nature, Aristotle's perspective has been marked as an expression of anthropocentric teleology (see [A] above). ${ }^{30}$ According to this reading, in Aristotle's worldview things are so arranged that the entire contents of the natural world exist and function only for the benefit of human beings. While god remains the highest thing and the ultimate object of aspiration, human beings are the ultimate beneficiary of the contents of the natural world. ${ }^{31}$

The anthropocentric reading of Aristotle's teleology appears to be supported especially by an over-cited passage from the Politica, where Aristotle states that plants exist for the sake of animals, and lower animals for the sake of humans:

[T7] In like manner we may infer that, after the birth of animals, plants exist for their sake, and that the other animals exist for the sake of man, the tame for use and food, the wild, if not all at least the greater part of them, for food, and for the provision of clothing and various instruments. Now if nature makes nothing incomplete, and nothing in vain, the inference must be that she has made all animals for the sake of man. (Aristotle, Politica I.8, 1256b11-22) ) $^{32}$

Now, anthropocentric teleology is a view on the world's interactive structure examined as a whole. This kind of global or universal teleology never surfaces in Aristotle's zoological works. ${ }^{33}$ Aristotle does not extend the workings of finality in nature beyond the structures and processes of individual organisms. ${ }^{34}$

It is significant that a passage where human being is explicitly treated as "beneficiary" of the natural environment is from Aristotle's treatise on Politica. The aim

d'Aristote: Fortune antique et médiévale (Paris: Publications de la Sorbonne, 2010): 11-30; Pavel Gregoric, "Plato's and Aristotle's Explanation of Human Posture," in Rizhai 2 (2005) 2: 183-196.

${ }^{30}$ David Sedley, “Is Aristotle's Teleology Anthropocentric?”, Phronesis 36 (1991) 2: 179-196.

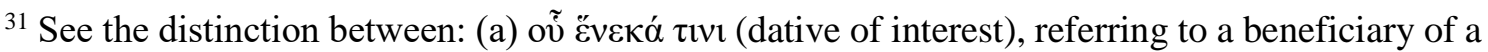

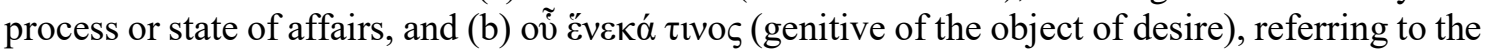
aim or object of aspiration of a process or a state of affairs. Wolfang Kullmann, "Different Concepts of the Final Cause in Aristotle", in Alan Gotthelf, ed., Aristotle on Nature and Living Things (Pittsburgh: Mathesis Publications, 1985): 170-175.

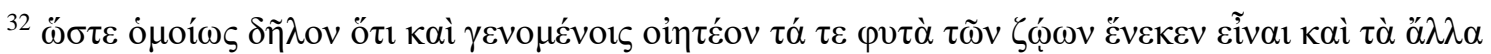

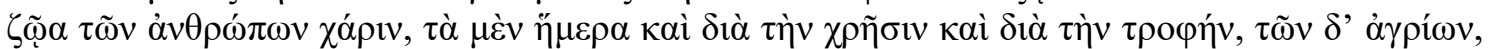

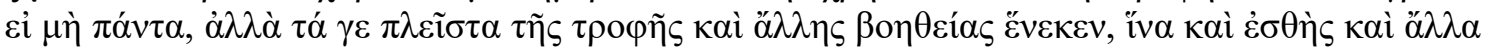

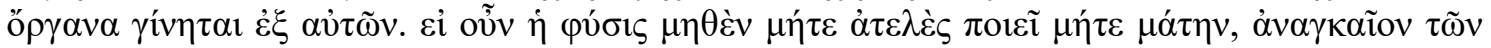

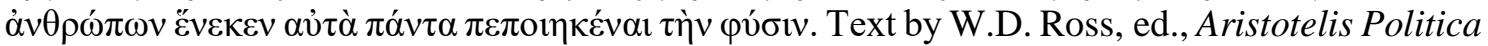
(Oxford: Clarendon Press, 1957), tr. by Benjamin Jowett, ed., The Politics of Aristotle (Oxford: Clarendon Press, 1885).

${ }^{33}$ By David Sedley's own admission: “Is Aristotle's Teleology Anthropocentric?”, cit. at 195.

${ }^{34}$ See esp. Robert Wardy, “Aristotle Rainfall or the Lore of Averages”, Phronesis 38 (1993): 1833. 
of T7 is not to state a scientific thesis on the cosmic hierarchy; rather, Aristotle is here willing to provide, "from the human-practical viewpoint" 35 , arguments for the naturalness of acquiring the necessities of household subsistence. To this end, he grounds his reasoning on the assumption that human beings are the beneficiary of nature, so to show that human acquisitiveness is founded in the natural order of things. But when he comes to his scientific treatment of nature and of its content - that is, in the works of natural philosophy, including his biological treatises - he does not even mention this hypothesis. By claiming that plants and animals are for the sake of human beings, Aristotle wants to highlight that human beings are natural beings that are dependent on them for subsistence and thus that human acquisitiveness is natural. But this does not imply that for him human beings are allowed to use and consume everything, or that nonhuman living beings have no value other than the instrumental. What is especially important for the present concern, I now want to argue, is that Aristotle regards all living beings as having intrinsic value, and this places constraints on any possible attitude of dominion. ${ }^{36}$

It is certainly safe to assert that from the standpoint of Aristotle's philosophy of biology human beings are the most complex forms of life on earth and that this complexity gives them a "special place" in the sublunary world, as ontologically superior to other embodied forms of life. Nevertheless, his defense of the study of biology in De Partibus Animalium I.5 (T3) clearly indicates that all life forms deserve to be equally observed and studied. The order Aristotle establishes within the scala naturae is functional to a better knowledge of the object of investigation: by starting from what is of "greater value" (because it is more complex), it is in fact possible to obtain a better knowledge of what is of "lesser value" (that is, simpler). This is the reason why the study of the anatomy and physiology of the human being actually constitutes the starting point of Aristotle's investigation on the anatomy and physiology of other living beings. ${ }^{37}$

35 Martha Craven Nussbaum, ed., Aristotle's De Motu Animalium (Princeton: Princeton University Press, 1978): 59-106 at 96. See also Lindsay Judson, “Aristotelian Teleology," Oxford Studies in Ancient Philosophy 29 (2005): 341-366 at 357-358.

${ }^{36}$ Obviously, there is the problem of adjudicating between the conflicting ends of living beings. A simple example might be that of nutrition - a diet of meat or vegetables, since both animals and plants are living beings according to Aristotle. At this, Alain Ducharme points out that in the very same chapter from which T7 is taken, Aristotle establishes a boundary of acquisition, namely "no more than it is required for survival": cf. Pol. I.8, 1256b27-37 with Alain Ducharme, "Aristotle on Dominion", cit. at 213-214.

${ }^{37}$ Cf. G.E.R. Lloyd, Science, Folklore and Ideology: Studies in the Life Sciences in Ancient Greece (Cambridge: Cambridge University Press, 1983): ch. 1.3. 
Acquiring the widest and most profound knowledge of the living nature is in a certain sense a duty for the human being. The human being is in fact characterized by the possession of the intellective power (voũ $\varsigma$ ), which places him in the privileged position of having the potential to know and understand (cf. de An. III.4, 429a10-11). Moreover, thanks to the voũs, human being is also capable of perceiving the good and the evil, and to share these moral perceptions with other members of his species through language (cf. Pol. I.2, 1253a7-18). Since the potentials to understand the world and to form moral and political communities are the distinguishing features of human beings, the actualization of these capacities is the achievement of human nature; in other words, in order to be "truly" human, one has to actualize his intellective and moral-political potentials. It is in this sense that the human being does have moral duties toward living beings other-thanhumans, namely those of understanding the $\tau \dot{\lambda} \lambda \mathrm{o} \varsigma$ of each of them.

Aristotle is certainly not immune from the inclination to paint humans as being "superior" in relation to other living beings; but human ontological superiority (see [S] above) is not incompatible with the attribution of intrinsic value to all living beings. This view on living nature might be seen as the result of undermining the threefold connection of [A] anthropocentric teleology, [S] human ontological superiority, and [D] human dominion on which human exploitation of nature is based. By maintaining [S], Aristotle is not outside of the anthropocentric perspective; but by grounding it on human greater but not exclusive - dignity, he can attribute intrinsic value also to beings other-thanhuman, against $[\mathrm{A}]$. Moreover, by conceiving of the realization of human nature as the actualization of a set of natural potentials, including those for knowledge and for morality, he provides human beings not only with rights but also with duties toward other living beings, thus holding a different version of [D].

\section{Concluding Remarks}

It is noteworthy that in late antiquity both Genesis and Aristotle's biological works had a common destiny: a selective approach, oriented more by interests in anthropology and theology than by a focus on plants and animals for themselves, as bearers of intrinsic value. It is this tradition of the texts, rather than the texts themselves, that constitutes the foundation of axiological anthropocentrism, which is blamed by Lynn White and other environmentalists for Western exploitative attitude toward nature. Their rethinking of the relationship of human beings to the natural environment reflects a widespread perception 
in the Sixties that the twentieth century was facing a serious environmental crisis. This widespread perception then resulted in the birth of Environmental Ethics as an academic discipline. This "new" academic discipline ${ }^{38}$ attempted to pose a challenge to axiological anthropocentrism, by questioning the assumed superiority of human beings to members of other species on earth, and investigating the possibility of rational arguments for assigning intrinsic value to the natural environment and its nonhuman content. While the role of the biblical tradition in these discussions has been embraced or dismissed, but in any case debated, Aristotle's philosophy of biology has not yet received the attention that, I argued in this essay, it deserves. ${ }^{39}$

Giulia Mingucci

University of Bologna

\section{References}

The Holy Bible, Revised Standard Version (Toronto, New York, Edinburgh: Thomas Nelson \& Sons, 1952).

Brennan Andrew and Lo, Yeuk-Sze. "Environmental Ethics", in Edward N. Zalta, ed., The Stanford Encyclopedia of Philosophy (Summer 2020 Edition). URL = https://plato.stanford.edu/ archives/sum2020/entries/ethics-environmental/.

Calarco, Matthew. "Being Toward Meat: Anthropocentrism, Indistinction, and Veganism", in Dialectical Anthropology 38 (2014) 4: 415-429.

Callicott, J. Baird. "Genesis Revisited: Murian Musings on the Lynn White, Jr. Debate", Environmental History Review 14 (1989) 1/2: 65-90 .

Carbone, Andrea. "Anomalies de l'intelligence, intelligence de l'anomalie: Note sur la représentation de l'organisation du corps vivant chez Aristote entre les Parva Naturalia et les Problèmes", in C. Grellard and P.-M. Morel, ed., Les Parva Naturalia d'Aristote: Fortune antique et médiévale (Paris: Publications de la Sorbonne, 2010): 11-30.

\footnotetext{
${ }^{38}$ See, however, Munamato Chemhuru, "Elements of Environmental Ethics in Ancient Greek Philosophy", Phronimon 18 (2017): 15-30, on the fallacy of considering environmental ethics as a "new" discipline.

${ }^{39}$ Aristotle's ethics and the Neo-Aristotelian "virtue ethics", instead, have witnessed a revival in the research field of environmental ethics: see e.g. Susanne Foster, "Aristotle and the Environment," Environmental Ethics 24 (2002) 4: 409-428. To my knowledge, only Alain Ducharme ("Aristotle and the Dominion of Nature," cit.) and Trish Glazebrook ("Art or Nature: Aristotle, Restoration Ecology, and Flowforms," Ethics and the Environment 8 [2003] 1: 22-36) ground their reflections on Aristotle and the natural environment in his philosophy of nature, but without referring to his biological treatises - which I instead consider fundamental to understand Aristotle's attribution of intrinsic value to all life forms.
} 
Cerami Cristina and Falcon, Andrea. "Continuity and Discontinuity in the Greek and Arabic Reception of Aristotle's Study of Animals", Antiquorum Philosophia, 8 (2014): 35-56.

Chemhuru, Munamato. "Elements of Environmental Ethics in Ancient Greek Philosophy", Phronimon 18 (2017): 15-30.

Cohen, Jeremy. "Be Fertile and Increase, Fill the Earth and Master It": The Ancient and Medieval Career of a Biblical Text (Ithaca, N.Y., and London: Cornell University Press, 1989).

Crist, Eileen and Kopnina, Helen. "Unsettling Anthropocentrism", in Dialectical Anthropology 38 (2014) 4: 387-396.

Ducharme, Alain. "Aristotle and the Dominion of Nature", Environmental Ethics 36 (2014) 2: 203-214.

Eugene C. Hargrove, "Weak Anthropocentric Intrinsic Value", The Monist 75 (1992) 2: 183-207. Falcon, Andrea. Aristotelismo (Torino: Einaudi, 2017).

Falcon, Andrea. Aristotle and the Science of Nature (Cambridge: Cambridge University Press, 2005).

Glazebrook, Trish. "Art or Nature: Aristotle, Restoration Ecology, and Flowforms", Ethics and the Environment 8 (2003) 1: 22-36.

Gregoric, Pavel. "Plato's and Aristotle's Explanation of Human Posture", in Rizhai 2 (2005) 2: 183-196.

Grey, William. "Environmental Value and Anthropocentrism", Ethics and the Environment 3 (1998) 1: 97-103.

Harrison, Peter. "Subduing the Earth: Genesis 1, Early Modern Science, and the Exploitation of Nature", The Journal of Religion 79 (1999) 1: 86-109.

Hett, W.S. Aristotle: On the Soul, Parva Naturalia, On Breath (Cambridge, Mass., London: LOEB, 1957).

Jobling, David. 'And Have Dominion... ', Dissertation (New York: Union Theological Seminary, 1972).

Jobling, David. “'And Have Dominion...': The Interpretation of Genesis 1,28 in Philo Judaeus”, Journal for the Study of Judaism in the Persian, Hellenistic, and Roman Period 8 (1977) 1: 5082.

Johansen, Thomas. "From Craft to Nature: The Emergence of Natural Teleology", in L. Taub, ed., The Cambridge Companion to Ancient Greek and Roman Science (Cambridge: Cambridge University Press, 2020): 102-120.

Jowett, Benjamin. ed., The Politics of Aristotle (Oxford: Clarendon Press, 1885).

Judson, Lindsay. “Aristotelian Teleology”. Oxford Studies in Ancient Philosophy 29 (2005): 341366.

Keller, David. ed., Environmental Ethics: The Big Questions (Chichester, West Sussex: Wiley, 2010).

Kullmann, Wolfang. "Different Concepts of the Final Cause in Aristotle", in Alan Gotthelf, ed., Aristotle on Nature and Living Things (Pittsburgh: Mathesis Publications, 1985): 170-175.

Kullmann, Wolfgang. Aristoteles und die Moderne Wissenschaft (Stuttgart 1998).

Le Blond, J.M. ed., Aristote philosophe de la vie: Le livre premier du traité sur les Parties des Animaux (Paris: Aubier Éditions Montaigne, 1945).

Lennox, James. "The Disappearance of Aristotle's Biology: A Hellenistic Mystery", Apeiron 27 (1994): 7-24. 
Lennox, James. "The Place of Zoology in Aristotle's Natural Philosophy", in Robert W. Sharples, ed., Philosophy and the Sciences in Antiquity (Aldershot: Ashgate, 2005): 58-70.

Lennox, James. ed., Aristotle: On the Parts of Animals I-IV (Oxford: Oxford University Press, 2001).

Lloyd, G.E.R. Science, Folklore and Ideology: Studies in the Life Sciences in Ancient Greece (Cambridge: Cambridge University Press, 1983).

Louis, J. ed., Aristote: Les parties des animaux (Paris: Les Belles Lettres, 1956).

Mingucci, Giulia. "Una difesa dello studio della materia vivente: Aristotele, De Partibus Animalium I 5", Antiquorum Philosophia 14 (2020), pp. 159-175.

Nash, Roderick. The Rights of Nature (Madison: University of Wisconsin Press, 1988).

Nussbaum, Martha, ed., Aristotle's De Motu Animalium (Princeton: Princeton University Press, 1978).

Perfetti, Stefano. Aristotle's Zoology and Its Renaissance Commentators (1521-1601) (Leuven: Leuven University Press, 2000).

Ross, W.D. ed., Aristotle: Parva naturalia (Oxford: Clarendon Press, 1955).

Ross, W.D. ed., Aristotelis Politica (Oxford: Clarendon Press, 1957).

Sedley, David. “Is Aristotle's Teleology Anthropocentric?”, Phronesis 36 (1991) 2: 179-196.

Simkins, Ronald. "The Bible and Anthropocentrism: Putting Humans in Their Place", Dialectical Anthropology 38 (2014) 4: 397-413.

Susanne Foster, “Aristotle and the Environment”, Environmental Ethics 24 (2002) 4: 409-428.

Wardy, Robert. "Aristotle Rainfall or the Lore of Averages”, Phronesis 38 (1993): 18-33.

White, Lynn. "The Historical Roots of our Ecological Crisis", Science 155 (1967): 1203-1207. 